\title{
Cell length measurements in longitudinal smooth muscle strips of the pig urinary bladder
}

\author{
E. van Asselt, R. Schot, R. van Mastrigt \\ Department of Urology, Erasmus University Rotterdam, P.O. Box 1738, NL-3000 DR Rotterdam, The Netherlands \\ Received: 18 February 1993 /Accepted: 16 April 1993
}

Summary. In this study the length of smooth muscle cells in muscle bundles of pig urinary bladder wall was determined after dissection in Tyrode buffers with different calcium concentrations $\left(\left[\mathrm{Ca}^{2+}\right]\right)$. Previous studies have shown that the length of isolated smooth muscle cells decreases with an increase in $\left[\mathrm{Ca}^{2+}\right]$ in the buffer. Unlike the results in isolated cells, no significant differences in length were found between cells in strips subjected to different $\left[\mathrm{Ca}^{2+}\right]$. Cells in bundles dissected from filled bladders were significantly larger than those dissected from emptied bladders. Cells in strips from emptied bladders dissected in $1.8 \mathrm{mM} \mathrm{Ca}^{2+}$-Tyrode buffer were shorter than those obtained in $\mathrm{Ca}^{2+}$-free buffer. From the measurements it was concluded that: (1) Cell length in intact tissue is directly related to tissue length; series elastic structures external to the cells do not allow significant shortening of the cells. (2) Passive parallel elasticity outside the cells accounts for passive shortening when bladders are emptied manually. (3) Cell length is not related to empty bladder weight. (4) A positive relation exists between empty bladder weight and bladder capacity.

Key words: Calcium - Cell size - Contraction - Smooth muscle

To understand the contractile properties of the urinary bladder, the organization and function of the elements composing the bladder wall have to be investigated. This knowledge is indispensable for the interpretation of urodynamic measurements in patients.

The wall of the urinary bladder is composed of numerous muscle bundles which do not seem to be organized in a specific pattern. Within the bundles, single

Correspondence to: E. van Asselt smooth muscle cells are mutually attached and are lined up in series and in parallel. In our laboratory we have concentrated on the measurement of the mechanical properties of muscle bundles and on the isolation of smooth muscle cells from the urinary bladder of the pig [7]. In muscle bundles or strips the relationships of neighboring cells can be studied, whereas in single cells attention is focused on the contractile properties of one cell $[9,16]$.

Previously we found that the size of isolated cells depended on the calcium concentration, $\left[\mathrm{Ca}^{2+}\right]$, of the buffer in which the isolation procedure was carried out: the higher the $\left[\mathrm{Ca}^{2+}\right]$, the shorter (smaller) the cells [15]. In this paper, results from experiments on isolated cells are discussed in the light of similar measurements on cells in muscle bundles where cells are in a more physiological environment. Strips of muscle tissue were dissected from filled and emptied bladders and immersed in buffers with different $\left[\mathrm{Ca}^{2+}\right]$. Cells were measured in longitudinal cryostat sections cut from the frozen muscle strips. By comparing measurements from single cells and from cells in strips, the effects of the $\left[\mathrm{Ca}^{2+}\right]$ and of the isolation procedure were evaluated. The results are discussed in terms of a model that comprises properties of contractile smooth muscle cells and their elasticity in series and in parallel.

\section{Materials and methods}

Pig bladders were obtained from the local slaughterhouse. The urethras of the filled bladders were tied to prevent urine from leaking out, and the bladders transported to the laboratory on ice. In order to obtain material from the anterior wall of the bladder in the stretched (filled) state, a piece of $3 \times 3 \mathrm{~cm}$ polyvinyl chloride with eight needles along the sides was placed on top of the bladder, the needles sticking through the anterior wall. The selected piece of stretched tissue was cut from the bladder wall and pinned to the silicone-covered bottom of a glass vial. The volume of urine contained in the bladder and the weight of the emptied bladder were determined.

The tissue was immersed in a $\mathrm{Ca}^{2+}$-Tyrode buffer $(137 \mathrm{mM} \mathrm{NaCl}$, $2.7 \mathrm{mM} \mathrm{KCl}, 1.0 \mathrm{mM} \mathrm{MgCl}_{2}, 12.5 \mathrm{mM}$ HEPES and $5.6 \mathrm{mM}$ glucose, 


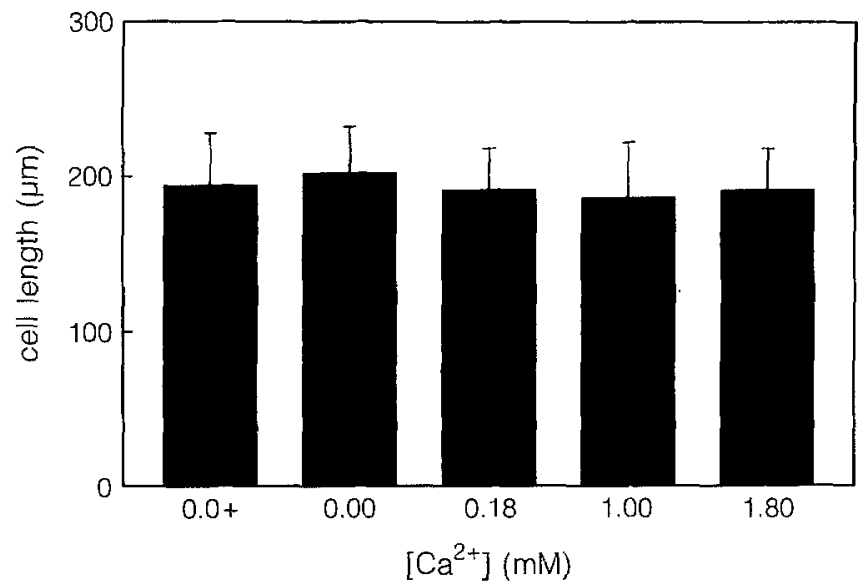

Fig. 1. Histogram showing cell lengths of smooth muscle cells (mean $\pm \mathrm{SD}, \mu \mathrm{m})$ in stretched strips from the urinary bladder of the pig. The strips were dissected in buffers with different $\mathrm{Ca}^{2+}$ concentrations (see Table 1)

pH $7.4,22^{\circ} \mathrm{C}$ ). The $\left[\mathrm{Ca}^{2+}\right]$ varied in each experiment: $0.0 \mathrm{mM}+$ $2 \mathrm{mM}$ EGTA, $0.0 \mathrm{mM}, 0.18 \mathrm{mM}, 1.0 \mathrm{mM}$ or $1.8 \mathrm{mM}$. Muscle strips were dissected from the exposed sclerosal side of the bladder wall. Two silk threads (0.7 metric 6-0 Ethicon) were tied around either end of a strip about $6 \mathrm{~mm}$ apart. The dissected strips were mounted at their original length on a piece of dental wax and were subsequently frozen in isopentane cooled in liquid nitrogen $\left(-160^{\circ} \mathrm{C}\right)$. Thereafter the tissue was transferred to a cryostat kept at $-25^{\circ} \mathrm{C}$, and $5-\mu \mathrm{m}$ longitudinal sections were cut. The sections were mounted on chrome-aluin-coated glass slides, which were subjected to a periodic acid Schiff (PAS) reaction. This (muco)polysaccharide stain results in blue-stained cell nuclei and red-stained basal membranes. The dark staining of the basal membrane facilitated the measurement of cell lengths. Cells were measured with the aid of a Videoplan (Zeiss Kontron). The image (magnification $12.5 \times 40$ ) formed in the light microscope was projected on to an $\mathrm{X}-\mathrm{Y}$ tablet by means of a drawing tube attached to the microscope. With the aid of a mouse device, lengths were measured of those cells that could be followed along their entire length, from tapering end to tapering end. Measurements were made without knowledge of the buffer $\left(=\left[\mathrm{Ca}^{2+}\right]\right)$ in which the strips had been dissected. One or two strips were studied from each bladder; ten cells were measured in each strip.

In total 26 bladders ( 388 cells) were investigated, 7 in $0.0 \mathrm{mM}$ $\mathrm{Ca}^{2+}+$ EGTA (99 cells), 4 in $0.0 \mathrm{mM} \mathrm{Ca}{ }^{2+}(50$ cells), 6 in $0.18 \mathrm{mM}$ $\mathrm{Ca}^{2+}(109$ cells $), 6$ in $1.0 \mathrm{mM} \mathrm{Ca}{ }^{2+}(80$ cells $)$ and 3 in $1.8 \mathrm{mM} \mathrm{Ca}^{2+}(50$ cells) (Table 1). Strips were also obtained from four bladders after they had been emptied: two bladders at $0.0 \mathrm{mM} \mathrm{Ca}^{2+}(40$ cells $)$ and 2 bladders at $1.8 \mathrm{mM} \mathrm{Ca}^{2+}$ (40 cells) (Table 2). These strips were fixed without any attempt to keep them at their original length. The cells from these strips were compared with the ones obtained from the same bladder while it was still filled (stretched). The single cells described by Schot et al. [15] were obtained under the same conditions from the same bladders. The Mann-Whitney $U$-test (MWU) was applied to compare samples and Spearman's rank coefficients were calculated to investigate the relations between the variables (significance level 0.05 ).

\section{Results}

Five groups of bladders were defined, corresponding to the five different buffers used. The mean cell length \pm SD in each of the groups was determined: group $1\left(0.0 \mathrm{Ca}^{2+}+\right.$ EGTA), $194 \pm 34 \mu \mathrm{m}$; group $2\left(0.0 \mathrm{Ca}^{2+}\right), 202 \pm 30 \mu \mathrm{m}$; group $3\left(0.18 \mathrm{Ca}^{2+}\right), 191 \pm 27 \mu \mathrm{m}$; group $4\left(1.00 \mathrm{Ca}^{2+}\right)$,
Table 1. Mean cell length $+\mathrm{SD}$, bladder weight and volume of urine of all 26 bladders investigated

\begin{tabular}{|c|c|c|c|c|c|}
\hline \multirow[t]{2}{*}{ Bladder } & \multirow[t]{2}{*}{$\begin{array}{l}{\left[\mathrm{Ca}^{2+}\right]} \\
(\mathrm{mM})^{\mathrm{a}}\end{array}$} & \multirow[t]{2}{*}{$\begin{array}{l}\text { Weight } \\
\text { (g) }\end{array}$} & \multirow[t]{2}{*}{$\begin{array}{l}\text { Volume } \\
\text { (ml) }\end{array}$} & \multicolumn{2}{|c|}{$\begin{array}{l}\text { Cell length } \\
(\mu \mathrm{m})\end{array}$} \\
\hline & & & & mean & SD \\
\hline 1 & $0.0+$ & 40 & 150 & 190 & 34 \\
\hline 2 & $0.0+$ & 60 & 220 & 202 & 30 \\
\hline 3 & $0.0+$ & 60 & 475 & 203 & 25 \\
\hline 4 & $0.0+$ & 45 & 305 & 158 & 24 \\
\hline 5 & $0.0+$ & 70 & 1230 & 175 & 33 \\
\hline 6 & $0.0+$ & 95 & 500 & 215 & 34 \\
\hline 7 & $0.0+$ & 60 & 310 & 206 & 26 \\
\hline Average & $0.0+$ & $63 \pm 18$ & $456 \pm 364$ & 194 & 34 \\
\hline 8 & 0.00 & 30 & 180 & 188 & 30 \\
\hline 9 & 0.00 & 110 & 45 & 207 & 37 \\
\hline 10 & 0.00 & 57 & 340 & 206 & 31 \\
\hline 11 & 0.00 & 40 & 122 & 200 & 9 \\
\hline Average & 0.00 & $59 \pm 36$ & $172 \pm 125$ & 202 & 30 \\
\hline 12 & 0.18 & 60 & 335 & 182 & 28 \\
\hline 13 & 0.18 & 70 & 400 & 166 & 17 \\
\hline 14 & 0.18 & 55 & 320 & 191 & 26 \\
\hline 15 & 0.18 & 50 & 300 & 190 & 31 \\
\hline 16 & 0.18 & 50 & 210 & 208 & 18 \\
\hline 17 & 0.18 & 50 & 140 & 194 & 21 \\
\hline Average & 0.18 & $55 \pm 9$ & $283 \pm 94$ & 191 & 27 \\
\hline 18 & 1.00 & 20 & 55 & 184 & 31 \\
\hline 19 & 1.00 & 55 & 200 & 232 & 32 \\
\hline 20 & 1.00 & 50 & 260 & 152 & 21 \\
\hline 21 & 1.00 & 87 & 240 & 150 & 19 \\
\hline 22 & 1.00 & 52 & 200 & 188 & 28 \\
\hline 23 & 1.00 & 60 & 375 & 197 & 23 \\
\hline Average & 1.00 & $46 \pm 29^{\circ}$ & $221 \pm 104$ & 186 & 36 \\
\hline 24 & 1.80 & 75 & 400 & 181 & 24 \\
\hline 25 & 1.80 & 47 & 175 & 201 & 25 \\
\hline 26 & 1.80 & 50 & 170 & 195 & 28 \\
\hline Average & 1.80 & $57 \pm 15$ & $248 \pm 131$ & 192 & 27 \\
\hline
\end{tabular}

a Five groups were defined by the $\left[\mathrm{Ca}^{2+}\right]$ in the $\mathrm{Ca}^{2+}$-Tyrode buffer: $0.0 \mathrm{mM} \mathrm{Ca}^{2+}+2 \mathrm{mM}$ EGTA; $0.0 \mathrm{mM} \mathrm{Ca}^{2+} ; 0.18 \mathrm{mM} \mathrm{Ca}^{2+} ; 1.0 \mathrm{mM}$ $\mathrm{Ca}^{2+} ; 1.8 \mathrm{mM} \mathrm{Ca}^{2+}$

$186 \pm 36 \mu \mathrm{m}$; and group $5\left(1.8 \mathrm{Ca}^{2+}\right), 192 \pm 27 \mu \mathrm{m}$ (Fig. 1, Table 1). It is clear that there were no significant differences among the five groups with respect to cell length. This is in contrast with the findings in single cells, where a decrease in cell length was found with an increase in $\left[\mathrm{Ca}^{2+}\right]$ [15].

When empty bladder weight and volume of urine of all bladders were tested, the Spearman rank correlation coefficient was $0.601(p<0.001)$; thus, heavy bladders contained more urine. When cells in the unstretched strips, dissected from the emptied bladders, were measured and compared with cells from stretched strips, significant differences in cell lengths were found: $160 \pm 29 \mu \mathrm{m}$ vs $204 \pm 26 \mu \mathrm{m}$ in $0.0 \mathrm{mM} \mathrm{Ca}^{2+}$, and $146 \pm 30 \mu \mathrm{m}$ vs $198 \pm 27 \mu \mathrm{m}$ in $1.8 \mathrm{mM} \mathrm{Ca}^{2+}$ (Table 2 ). Both pairs were significantly different (MWU, $P<0.001$ ). Moreover, the cells from emptied bladders measured in 
Table 2. Mean cell length \pm SD, bladder weight and volume of urine in those bladders from which strips were dissected in the filled and empty condition in $0.0 \mathrm{mM}$ or $1.8 \mathrm{mM} \mathrm{Ca}^{2+}$

\begin{tabular}{lllllr}
\hline Bladder & $\begin{array}{l}{\left[\mathrm{Ca}^{2+}\right]} \\
(\mathrm{mM})\end{array}$ & $\begin{array}{l}\text { Weight } \\
(\mathrm{g})\end{array}$ & $\begin{array}{l}\text { Volume } \\
(\mathrm{ml})\end{array}$ & \multicolumn{2}{l}{$\begin{array}{l}\text { Cell length } \\
(\mu \mathrm{m})\end{array}$} \\
\cline { 3 - 6 } & & & & Mean & SD \\
\hline 10 & 0.00 & 57 & 340 & 206 & 31 \\
11 & 0.00 & 40 & 122 & 200 & 9 \\
Average & 0.00 & $49 \pm 12$ & $231 \pm 154$ & 204 & 26 \\
10 emptied & 0.00 & 57 & 0 & 149 & 20 \\
11 emptied & 0.00 & 40 & 0 & 171 & 33 \\
Average & 0.00 & $49 \pm 12$ & 0 & 160 & 29 \\
25 & 1.80 & 47 & 175 & 201 & 25 \\
26 & 1.80 & 50 & 170 & 195 & 28 \\
Average & 1.80 & $49 \pm 2$ & $173 \pm 4$ & 198 & 27 \\
25 emptied & 1.80 & 47 & 0 & 166 & 25 \\
26 emptied & 1.80 & 50 & 0 & 127 & 20 \\
Average & 1.80 & $49 \pm 2$ & 0 & 146 & 30 \\
\hline
\end{tabular}

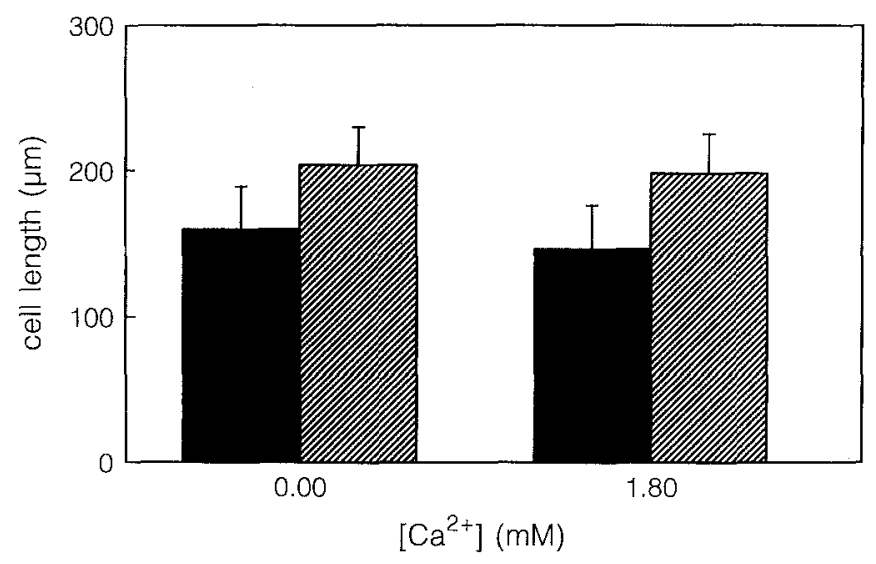

Fig. 2. Histogram showing cell lengths of smooth muscle cells (mean $\pm \mathrm{SD}, \mu \mathrm{m})$ in strips from emptied bladders and in stretched strips obtained in 0.0 and $1.8 \mathrm{mM} \mathrm{Ca}^{2+}$ buffer (see Table 2); empty; एIII filled

$0.0 \mathrm{mM} \mathrm{Ca}^{2+}$ were significantly longer than the ones measured in $1.8 \mathrm{mM} \mathrm{Ca}^{2+}$ (MWU, $P<0.024$ ) (Fig. 2, Table 2). When the Spearman correlation test was applied to cell length and bladder weight and to cell length and volume of urine, no correlation was found, except for $0.18 \mathrm{mM} \mathrm{Ca}^{2+}$.

\section{Discussion}

A simple model describing both passive and active properties of muscle bundles within the bladder wall implies series elasticity in series with contractile muscle cells, and passive elasticity in parallel with both (Fig. 3)

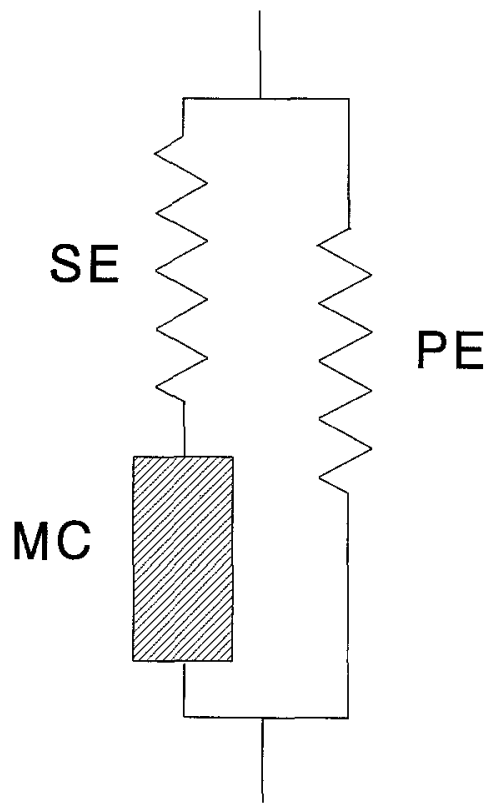

Fig. 3. A simple model of the bladder wall implies series elasticity $(S E)$ in series with contractile muscle cells $(M C)$ and parallel elasticity $(P E)$ in parallel with both

[12]. Some of the elastic properties of the tissue can be ascribed to the smooth muscle cells themselves, but a significant part resides outside the cells [12].

It is unclear exactly what the anatomical substrates of the elastic properties are. In smooth muscle the major component in the extracellular space is collagen. Microfibrils and ill-defined densities have been described between collagen fibrils and basal laminae, and it is likely that these constitute a mechanical link between cell membrane and collagen framework [6]. Smooth muscle cells within the muscle bundles are closely packed together, attached to neighboring cells by junctions [8].

In the present study it was found that the mean length of cells in pig bladder strips which were fixed at the in situ length was $193 \mu \mathrm{m}$ (range 186-202 $\mu \mathrm{m}$ ) and did not depend on the $\left[\mathrm{Ca}^{2+}\right]$ of the bathing solution. In the literature a large range of smooth muscle cell lengths has been described $[1,2,4,5,10,11,14,17]$, from $100 \mu \mathrm{m}$ in vas deferens muscle cells of the rat [14] to $500 \mu \mathrm{m}$ in cells from the taenia coli of the guinea pig $[4,5]$.

In isolated cells a clear relation was found between cell length and $\left[\mathrm{Ca}^{2+}\right]$ : the higher the $[\mathrm{Ca} 2+]$ the shorter the cells [15]. Assuming that $\left[\mathrm{Ca}^{2+}\right]$-dependent shortening of the isolated cells was an active process, we conclude that either the single cells were stimulated whereas the cells in the strips were not, or the shortening of the cells in the strips was prevented by a non-compliant series elasticity. The resuspension of the cells during the isolation procedure may have affected the potential of the plasma membrane and by doing so caused an inflow of $\mathrm{Ca}^{2+}$ which resulted in a shortening (contraction) of the cells. However, the cells in strips (not stimulated by resuspension) dissected from the emptied bladders also showed a $\left[\mathrm{Ca}^{2+}\right]$-dependent length as opposed to the cells in strips 
from filled bladders. We therefore conclude that the length of cells in intact tissue is directly related to the tissue length. Series elasticity external to the cells does not allow the cells to shorten when the tissue length is fixed (Fig. 3). Lengthening of cells in strips is probably caused by extracellular changes such as filling of the bladder. Parallel collagen fibrils attached to the basal lamina may put restrictions on the shortening or lengthening range of the muscle cells.

Cells in strips from bladders that had been emptied were significantly shorter than cells in strips from (the same) filled bladders. Since the shortening also occurred in $\mathrm{Ca}^{2+}$-free medium and no shortening seems to have taken place in the isolated cells at $\left[\mathrm{Ca}^{2+}\right]=0.0 \mathrm{mM}$ (these cells were considerably longer than the cells in strips), it is very likely that the shortening resulted from passive elasticity which might be inherent in the cells or from passive external structures (Fig. 3). This elasticity outside the cells is probably the basis for the passive properties that dominate the urinary bladder during the collection phase [13].

The empty bladder weight (range $20-110 \mathrm{~g}$ ) and the volume of urine (range $55-1230 \mathrm{ml}$ ) were significantly correlated, heavy bladders containing more urine (see Table 1). We expect that the degree of bladder filling at slaughter varied randomly, being on average around half the bladder capacity. The correlation found between bladder weight and volume of urine therefore implies a relation between (empty) bladder weight and capacity. In the bladders used in this study there was no overall correlation between cell length and empty bladder weight. This implies that larger bladders do not have larger cells but have more cells of the same size. In contrast to this finding, Driska and Porter [2] stated that larger animals may have larger cells (assuming that larger animals have larger bladders).

Acknowledgement. We would like to thank the staff of the Department of Pathology and Anatomy, Erasmus University Rotterdam, for the use of their facilities (cryostat) and for performing the PAS staining.

\section{References}

1. Cooke PH, Fay FS (1972) Correlation between fiber length, ultrastructure, and the length-tension relationship of mammalian smooth muscle. J Cell Biol 52:105

2. Driska SP, Porter R (1986) Isolation of smooth muscle cells from. swine carotid artery by digestion with papain. Am J Physiol 251:C474

3. Fay FS, Delise CM (1973) Contraction of isolated smoothmuscle cells: structural changes. Proc Natl Acad Sci USA 70:641

4. Gabella G (1976) Quantitative morphological study of smooth muscle cells of the guinea pig taenia coli. Cell Tissue Res 170:161

5. Gabella G (1976) Structural changes in smooth muscle cells during isotonic contraction. Cell Tissue Res 170:187

6. Gabella G (1981) Structure of smooth muscles. In: Brading AF, Jones AW, Tomita $\mathrm{T}$ (eds) Smooth muscle: an assessment of current knowledge. Edward Arnold, London, p 1

7. Glerum JJ, Mastrigt R van, Romijn JC, Griffith DJ (1987) Isolation and individual electrical stimulation of single smooth muscle cells from the urinary bladder of the pig. J Muscle Res Cell Motil 8:125

8. Gosling JA, Dixon JS, Humpherson JR (1983) Functional anatomy of the urinary tract. Gower, London New York

9. Kelly RE, Rice RV (1969) Ultrastructural studies on the contractile mechanism of smooth muscle. J Cell Biol 42:83

10. Klockner U, Isenberg G (1985) Action potentials and net membrane currents of isolated smooth muscle cells (urinary bladder of the guinea pig). Pflügers Arch 405:329

11. Lane BP (1965) Alterations in the cytosolic detail of intestinal smooth muscle cells in various stages of contraction. $\mathrm{J}$ Cell Biol $27: 199$

12. Mastrigt $R$ van (1988) The length dependence of the series elasticity of pig bladder smooth muscle. J Muscle Res Cell Motil $9: 525$

13. Mastrigt R van, Coolsaet BLRH, Duyl WA van (1978) Passive properties of the urinary bladder in the collection phase. Med Biol Eng Comput 16:471

14. Nakazawa K, Matsuki N, Shigenobu K, Kasuya Y (1987) Contractile response and electrophysiological properties in enzymatically dispersed smooth muscle cells of rat vas deferens. Pflügers Arch 408:112

15. Schot R, Asselt E van, Mastrigt $R$ van (1993) A method for isolating smooth muscle cells from pig urinary bladder with low concentrations of collagenase and papain: the relation between calcium concentration and isolated cell length. Urol Res 21:49

16. Small J (1977) Studies on isolated smooth muscle cells: the contractile apparatus. Cell Sci $24: 327$

17. Warshaw DS, Szarek JL, Hubbard MS, Evans JN (1986) Pharmacology and force development of single freshly isolated bovine carotid artery smooth muscle cells. Circ Res 58:399 